be in charge one who is familiar with the rather special conditions which obtain there. To zoologists Prof. Jackson is best known for his numerous papers on the systematics of the terrestrial Isopod Crustacea and on the comparative anatomy of the Isopod head; but his colleagues are familiar, too, with the imperturbable good humour, the careful planning and the absolute fairness with which he has presided over numerous bodies in his College and University, while large numbers of former students recall with great enjoyment the lucidity and wit of his lectures, and his uncanny knack of selecting precisely the most apt metaphor or simile for driving home a point of difficulty. In view of the damage sustained by the College during the raids of $1940-41$ and the part which Birkbeck College is bound to play in University education after the War, the transfer of the College to the Bloomsbury site is one of its most urgent problems. Prof. Jackson's many high qualities will, we feel, ensure an early solution.

\section{Tercentenary of John Bainbridge}

When Sir Henry Savile (1549-1622), while holding the post of warden of Merton College, Oxford, founded the Savilian professorships of geometry and astronomy at Oxford in 1619, the first of these was given to Henry Briggs (1561-1630), who had held the chair of geomotry at Gresham College, London, while to the second was appointed John Bainbridge, a London physician who had just published a description of a comet observed in November 1618. Tainbridge on his appointment was thirty-seven, and he continued to hold his chair until his death on November 3, 1643. Born at Ashby-de-la-Zouche, he had studied at Emmanuel College, Cambridge, and had qualified in medicine. While teaching and practising he devoted his leisure to mathematics and astronomy. Removing to Oxford in 1620, he continued his study of the writings of the Greeks and Arabs, and though he published but little, he left a considerable number of manuseripts. These he bequeathed to his friend, the learned but unfortunate Archbishop James Ussher (1581-1656), whose library, after various vicissitudes, passed to Trinity College, Dublin. Bainbridge died at his house opposite Merton College, and after an oration by William Strode, his body was laid beside that of Briggs in Merton College Chapel.

\section{Aeronautical Medals}

The Royal Aeronautical Sociely has recently acquired, through the generosity of an anonymous donor, a remarkable collection of more than three hundred aeronautical medals, dating from 1714 to 1941. The medals are a veritable history of aeronautics, struck on the occasion of some aeronautical event. Three of the early medals were struck in 1783 to commemorate the first ascent of the Montgolfier Brothers' in a hot-air balloon; two others show the first ascent of Lunardi from London in 1784 ; another the first Dutch aeronaut to ascend, from Amsterdam, in 1806. James Sadler, the first Fnglishman to make an ascent, is commemorated in a medal dated 1811. A silver medal of 1851 shows the ascent of three balloonists each on a horse! There are many examples of the Siege of Paris medals of 1870, Giffard's ascents and others. A bronze medal of 1896 shows the Andrée polar balloon, and several silver ones of 1901 Santes Dumont's dirigible. Coming to later days, there is a medal of 1909 commemorating the award of the Congress Medal to the brothers Wright ; medals of various Zeppelins, Parseval, the $R .101$ and other dirigibles; medals commemorating Bleriot's cross-Channel flights, 1909 ; the flights of Paulhan (London-Manchester, 1910); Chavez (crossing the Alps, 1910); Lindbergh (trans-Atlantic flight, I927); Hinkler (London to Australia, 16 days, 1928); Kohl, Hunefeld and Fitzmaurice (Ireland to America, first east-west flight, 1928); and Prof. Picard and Dr. Kipfer (first stratosphere ascent, 1931).

\section{Collaboration in Fuel Research}

The Standing Consultative Conference on Fuel Research, which has been constituted by the Department of Scientific and Industrial Research to promote collaboration among the various research associations or equivalent organizations engaged on fuel research, and between them and the Department's Fuel Research Organisation, had a preliminary meeting on October 21 at which representatives of the Ministry of Fuel and Power, the British Coal Utilisation Research Association, the British Electrical and Allied Industries Research Association, the British Refractories Research Association, the Gas Research Board, British Iron and Steel Federation (Industrial Research Council), and British Hard Coke Research Association were present. In his opening remarks Sir Edward Appleton, who presided, briefly described the objects which the Department had in view in setting up the Conference, and emphasized that membership is voluntary and at the invitation of the Department. The Conference is intended to provide a convenient means whereby the research organizations may keep in close touch with cach other, and assist each other by interchange of information and by friendly discussion. Members of the Conference described briefly the aims and scope of their organizations and then discussed arrangements for the setting up of a central body to undertake the preparation and publication of abstracts of current literature relating to fuel and the maintenance of a register of translations. It was decided that the next meoting should be held carly in January 1944, when the fuel research programmes of the member organizations would be considered by tho Conference.

\section{Application of Biology to Agriculture}

Dr. Hubert Martin's presidential address to the Association of Applied Biologists, delivered on February 12,1943 , which has now appeared in the Annals of Applied Biology, pays tribute to the work of the Biology War Committee and expresses the view that the provincial advisers in the biological subjects may soon be expected to assert their proper and powerful influence on the activitios of the War Agricultural Executive Committees. Discussing the official recognition of proprietary pest control products, which has been brought into fresh prominence through the participation of the advisory services in the "Growmore" campaign, Dr. Martin outlined the negotiations between the Association and the British Mycological Society, the Ministry of Agriculture and the Association of British Insecticide Manufacturers which had led to the scheme announced in October for a joint panel to give the requisite guidance to the advisory committee. The further growth of the scheme, which will not admit products of wholly secret composition and which includes no testing 